\title{
TAX PLANNING FOR ESTATES UNDER THE NEW ESTATE AND GIFT TAX REGULATIONS*
}

\author{
Charles L. B. Lowndest
}

$T^{\prime}$ HE EASIEST way to appraise the impact of the new estate and gift tax regulations upon tax planning for estates is to consider the more common devices for minimizing estate and gift taxes and see how they are affected by the new regulations. In this connection, it will be convenient to consider the estate tax first and then the gift tax.

I

The Estate Tax

The discussion under the estate tax may be divided into: ( 1 ) intervivos gifts; (2) successive estates; (3) deductions; and (4) valuation.

\section{A. Intervivos Gifts}

The most obvious way to avoid an estate tax is to give away property during life, in order to remove it from one's taxable estate at death. The practical disadvantage connected with this scheme is that it deprives the donor of the enjoyment of the property during his life. Consequently, prospective decedents are constantly casting about for some means by which to divest themselves of their belongings for tax purposes during life, without actually surrendering the substantial enjoyment of their property until their death. The problem which intervivos gifts poses to the tax planner is how to give away property during life, without relinquishing the substantial enjoyment of or control over the property before death, and without encountering the taxes which the estate tax imposes upon such transfers. Some of the answers to this prob-

* This article is based on a paper delivered at an Institnte on Current Problems in Federal and State Taxation, sponsored by the North Carolina Bar Association, at the Duke University School of Law, February 6, 1959.

† A.B. 1923, Georgetown University; LL.B. 1926, S.J.D. 1931, Harvard University. James B. Duke Professor of Law, Duke University; member of the New York, District of Columbia, and North Carolina bars. Co-author [with Robert Kramer], Federal Estate and Gift Taxes (1956). Contributor to legal publications. 
lem may be found in the new estate tax regulations relating to the various taxes upon intervivos transfers which are imposed by the statute.

\section{Transfers in contemplation of death}

Ordinarily, the estate tax does not attach to an intervivos transfer unless the transferor retains some interest in the transferred property until his death. An exception to this rule occurs, however, in connection with the tax upon transfers in contemplation of death. Even a complete indefeasible transfer may be taxed if it is made in contemplation of death.

The only sure way to avoid a tax upon a transfer as a transfer in contemplation of death is to persuade the transferor to live more than three years after the transfer, since there is a conclusive statutory presumption, ${ }^{1}$ which is recognized by the regulations, ${ }^{2}$ that such a transfer is not in contemplation of death.

If a transfer is made within three years of the transferor's death, there is a rebuttable presumption ${ }^{3}$ that the transfer is in contemplation of death. The new regulations, however, like the regulations under the 1939 Code, $^{4}$ define a transfer in contemplation of death in subjective terms of the transferor's state of mind, as a transfer "prompted by the thought of death." Consequently, the careful lawyer will make an effort to "preserve" evidence showing that transfers of a substantial part of his client's estate were not motivated by the thought of death for at least three years after the transfer.

An interesting problem, which arises in connection with the tax upon transfers in contemplation of death, is whether it is possible to avoid an estate tax upon an intervivos transfer which is taxed because the transferor retained some interest in the transferred property by releasing this interest in contemplation of death. Suppose, for example, that $A$ transferred property to $T$ in trust for $C$, reserving the income from the property to himself during his life. When $A$ feels that death is near, he releases his life estate in order to make sure that the trust property will not be taxed to his estate under the federal estate tax. Will the relinquishment of the life estate in contemplation of death take the prop-

\footnotetext{
${ }^{1}$ INT. REv. CODE OF 1954, $\$ 2503$ (b)."

' U.S. Treas. Reg. $\$ 20.2035 \div$ (d) (1958).

IINT. REv. CODE OF 1954, § 2035 (b).

U.S. Treas. Reg. 105, $\$ 8 \times .16$ (a) (1942).

${ }^{5}$ U.S. Treas. Reg. $\$ 20.2035-1$ (c) (1958).

- See Lowndes \& Rramer, Federal Estate and Gift Taxes 853 (1956).
} 
erty out of $A$ 's taxable estate, since he will have no interest in the property at his death, or will the trust property remain taxable to his estate upon the theory that he cannot avoid a tax by a transfer in contemplation of death? The regulations provide that ${ }^{7}$

If a decedent transfers an interest in property or relinquishes a power in contemplation of death, the decedent's gross estate includes the property subject to the interest of power to the extent that it would be included under section 2036,2037 , or 2038 , if the decedent had retained the interest or power until his death.

In other words, the regulations say that if a decedent releases a life estate which would make property taxable to his estate under section 2036 , or a reversionary interest which would attract a tax under section 2037 , or a power to alter or revoke a transfer which is taxed under section 2038 , in contemplation of death, the property subject to these interests shall be taxed to his estate to the same extent it would have been taxed if the relinquishment in contemplation of death had not occurred. It is not at all clear that this construction of the statute by the regulations is correct.

As far as the relinquishment of a power to alter or revoke a transfer in contemplation of death is concerned, it is clear that the property subject to the power remains taxable to the decedent's estate just as though the transfer in contemplation of death had not occurred, since section $2038(a)(1)$ and (2) expressly covers this contingency and provides for this result. However, section 2036 says nothing about what happens where a reserved life estate is relinquished in contemplation of death; nor does section 2037 make any provision for the release of a reversionary interest in contemplation of death. The relinquishment of these interests in contemplation of death is governed by section 2035, which taxes transfers in contemplation of death. Section 2035 provides for the inclusion in the decedent's gross estate "of any interest" which the decedent transferred in contemplation of death. It is arguable that under this language, where a reserved life estate or a reversionary interest is released in contemplation of death, only the value of the life estate or the reversionary interest-which would be worthless at the decedent's death-should be included in his gross estate.

In the only area in which there seems to have been any litigation of this problem, the courts have reached conclusions at variance with

\footnotetext{
${ }^{7}$ U.S. Treas. Reg. $§ 20.2035^{-1}$ (b) (I958).
} 
the regulations. In several cases where a joint tenant who paid all of the consideration for the jointly-held property transferred his interest in contemplation of death, it has been held that only the value of the transferor's proportionate share of the property, and not the total amount of the property which would have been taxed to his estate if the transfer had not occurred, can be taxed to his estate. ${ }^{8}$

\section{Transfers with a reservation of a life interest}

One way to give away property during life, without parting with the enjoyment of the property until death, is to make a gift of the property with a reservation of a life estate. This type of transfer is, of course, taxed under section 2036 of the estate tax.

Taxpayers have achieved the result of a transfer with a reservation of a life interest, however, without encountering the tax imposed by section 2036 by casting the transaction in the form of an exchange of property for a noncommercial annuity. Thus, for example, suppose that $A$ has $\$ 100,000$ worth of bonds which yield $\$ 5,000$ interest a year. He transfers these bonds to his son in exchange for the son's promise to pay him an annuity of $\$ 6,000$ a year as long as $A$ lives. It has been held that if $A$ retains no interest in the transferred property, this will be treated as the purchase of an annuity rather than a transfer with a reservation of a life estate, and the property transferred by $A$ will not be taxed to his estate. ${ }^{9}$ Although it is likely that the Treasury will seek to impose a tax upon such transactions because of their substantial resemblance to a transfer with a reservation of a life estate, they have escaped a tax in the past, and, at least, the new regulations do not explicitly provide that they are taxable.

The Supreme Court has recently pointed out a way to transfer property with a reservation of a life estate without incurring a tax under section 2036. In Fidelity-Philadelphia Trust Company v. Smith, ${ }^{10}$ the decedent, when he was past the age when he was insurable, purchased a single premium policy of life insurance together with an annuity from an insurance company. The company sold him the insurance since he also purchased the annuity, and the total premiums under both policies were more than the death benefit under the insurance policy. The com-

\footnotetext{
${ }^{8}$ Sullivan's Estate v. Commissioner, 175 F.2d 657 (gth Cir. 1949); see Lowndes, Cutting the Strings on Intervivos Transfers in Contemplation of Death, 43 MINN. L. REv. 57, 62 (1958).

- See Lowndes \& Kramez, Federal Estate and Gift Taxes x5I (1956).

${ }^{20} 356$ U.S. 274 (1958).
} 
pany took no risk, because if the insured lived, it could pay him the annuity, which represented a modest rate of interest upon the premiums paid for the policies, from the interest earned by the premiums; while if he died, the death benefit under the insurance policy was less than the decedent had already paid in premiums. The decedent completely assigned the insurance policy during his life, and when he died, the Supreme Court held that there was nothing which could be taxed to his estate, since the insurance policy was distinct from the annuity, and the decedent had completely divested himself of any interest in the insurance during his life. It is clear, of course, that the decedent did not actually buy insurance, since there was no insurance risk connected with the transaction. ${ }^{11}$ It is difficult to see that he did anything more than deposit a sum of money with the insurance company under an agreement by which the company undertook to pay him interest on this deposit during his life and at his death to pay over the deposit to his designated beneficiary. At any rate, as long as the decision in the Fidelity-Philadelphia Trust Company case stands, it is possible to transfer property with a reservation of a life estate without encountering the estate tax by casting the transfer in the form of a purchase of a life insurance policy and an annuity and an irrevocable gift of the insurance policy.

In one respect, the new estate tax regulations reflect a stiffer attitude about the tax upon transfers with a reservation of a life estate. Section 2036 imposes a tax where a man transfers property and retains the enjoyment of the property "for his life or for any period not ascertainable without reference to his death or for any period which does not in fact end before his death." The reason why the tax is imposed where the decedent does not retain a formal life estate, but keeps possession or enjoyment of the transferred property for a period not ascertainable without reference to his death, or for a period which does not, in fact, end before his death, is, of course, to prevent avoidance of the tax by transfers under which the transferor retains an interest which is not technically a life estate, but is the substantial equivalent of a life estate. Pursuant to this line of thought, the regulations under the 1939 Code provided that a decedent would not be deemed to have retained possession of property for a period which did not, in fact, end before his death unless he reserved possession "for such a period as to evidence his intention that it should extend for the duration of his life."12 The new regulations

\footnotetext{
${ }^{12}$ Helvering v. LeGierse, 312 U.S. 531 (1941).

${ }^{12}$ U.S. Treas. Reg. 105, §81.18 (1942).
} 
omit this interpretation. Apparently, under the new regulations, the statute will be applied literally. If a man gives his house to his son and dies suddenly before he can vacate the premises, the house will be taxed to his gross estate under section 2036. It seems desirable, therefore, when a man makes an intervivos transfer, in order to get the transferred property out of his taxable estate, to turn the possession of the property over at once to the transferee, instead of lingering in possession and running the risk of $a$ tax if the transferor dies unexpectedly. ${ }^{13}$

\section{Transfers taking effect at death}

Under section 811 (c) (3) of the 1939 Code, as amended by the 1949 Technical Changes Act, ${ }^{14}$ a transfer under which the possession or enjoyment of the transferee was dependent upon surviving the transferor was taxable as a transfer taking effect at death. Section 2037 of the 1954 Code changed this rule by limiting the tax upon transfers taking effect at death to transfers where not only is the transferee's possession or enjoyment dependent upon surviving the transferor, but, in addition, the transferor retained a reversionary interest in the transferred property which immediately before the transferor's death was worth more than five per cent of the value of the transferred property. The new regulations reflect this change in the law. They also interpret the reversionary interest requirement liberally by providing that the chance that the transferor may inherit the transferred property from the transferee is not a reversionary interest. ${ }^{15}$ Thus, for example, if $A$ transferred property to $T$ in trust, to accumulate, the income from the property for $B, A$ 's son, during $A$ 's life, and at $A$ 's death, to pay over the property and the accumulated income to $B$, the trust property would not be taxable to $A$ 's estate if $B$ survived him, even though $A$ was $B$ 's only relative and had a chance of inheriting the trust property from $B .^{16}$

${ }^{28}$ In Ambrose Fry, 9 T.C. 503 (1947), which seems to be the only case upon the point, the Tax Court reached a result apparently in accord with the new regulations. The court applied the statute literally to tax a decedent upon stock which he had transferred during his life, subject to the right to receive a specified amount of dividends, which had not been fully received at the time of his death.

${ }^{24} \S 7,63$ STAT. 891 (1949).

${ }^{25}$ U.S. Treas. Reg. $\$ 20.2037-1$ (c) (2) (1958).

${ }^{12}$ The committee reports which accompanied the 1954 Code, after pointing out that the reversionary interest which will sustain a tax under $\$ 2037$ must be worth more than $5 \%$ of the transferred property added that this requirement would be met if the decedent had one chance in twenty that the property would be returned to him (H.R. REP. No. 1337 , 83d Cong., 2d Sess. 90 (1954); S. Rep. No. 1622, 83d Cong., 2d Sess. 123 (1954)), although it would appear that in this situation, the reversionary interest would 


\section{Revociable transfers}

Under the new regulations, it is possible to transfer property during one's life without losing control of the property by making a transfer which can be altered or revoked by one other than the transferor, without the transferor's concurrence. The statute says that revocable transfers are taxable where the transferor alone, or the transferor in conjunction with any other person, can alter or revoke the transfer. ${ }^{17}$ The statute does not expressly provide for a tax where the trust can be altered or revoked by one other than the transferor. Several cases, interpreting the statute literally, have held that such transfers are not taxable. ${ }^{18}$ The new regulations accept these decisions. ${ }^{10}$ Thus, a man can transfer property to a trustee during his life and give the trustee power to revoke the trust without subjecting the transfer to the estate tax. In this connection, however, the new regulations provide that if power to alter or revoke a trust is given to the trustee and the settlor retains power to appoint himself trustee, the settlor has, in effect, retained power to alter or revoke the trust, and the trust property is taxable to his estate. ${ }^{20}$

Under section 2036, which taxes transfers with a reservation of a life interest, it is provided that a transfer under which the transferor, either alone or in conjunction with some other person, retains power to designate the income from or the possession of the transferred property during his life is taxable to the transferor's estate. The new regulations under section 2036, in line with the construction of section 2038, provide that no tax will be imposed under this section if a person, other than the decedent, is given power to designate the enjoyment of the transferred property. ${ }^{21}$ Here, again, however, the regulations provide that the settlor will be deemed to possess such a power if the trustee has power to designate the enjoyment of the property and the settlor retains power to make himself trustee. ${ }^{22}$

exactly equal $5 \%$ of the value of the transferred property instead of exceed it, as the statute requires. The regulations state simply that the value of the reversionary interest must exceed $5 \%$ of the value of the transferred property. U.S. Treas. Reg. $\$ 20.2037^{-1}$ (1958).

${ }^{17}$ INT. REv. CODE OF 1954, $\$ 2038$.

${ }^{18}$ Anna B. Kneeland, 34 B.T.A. 816 (1936); see Lowndes \& KRAMER, FEDERAL Estate AND GifT TAXES I 79-82 (1956).

${ }^{20}$ U.S. Treas. Reg. § 20.2038-1 (a) (3) (1958).

${ }^{20}$ Ibid. See Loughridge v. Comm'r, 183 F.2d 294 (1oth Cir. 1950); van Beuren v. McLaughlin, 161 F. Supp. 944 (D.R.I. 1958), aff'd, FED. Est. \& GiFT TAX REP. II I1,838 (1st Cir. 1958).

${ }_{21}$ U.S. Treas. Reg. \& 20.2036-I(b)(3) (x958).

${ }^{22}$ Ibid. 
In contrast to the regulations under the 1939 Code, ${ }^{23}$ the new regulations take the position that a power to alter or revoke a trust does not make the trust taxable to the settlor's estate if the settlor's power to alter or revoke the trust is subject to some contingency over which he has no control (other than giving notice or lapse of time) which has not occurred at the decedent's death. ${ }^{24}$ This conforms to the cases. ${ }^{25}$ Upon this point, however, the new regulations may well prove to be a tax trap rather than a loophole for the estate planner. Thus, for example, suppose that $A$ conveys property to $T$ in trust to pay the income to $C$ for life, remainder to $D$ and his heirs, and provides that if $A$ survives $C$, he shall have power to revoke the trust. If $A$ predeceases $C$, then according to the new regulations, the trust is not taxable to $A$ 's estate under section 2038. In this situation, however, it would appear that $A$ 's power to revoke the trust is also a power to designate the income from the trust, which is taxable under section 2036, and the regulations provide that a power to designate the enjoyment of property is taxable under section 2036, even though "the exercise of the power was subject to a contingency beyond the decedent's control which did not occur before his death (e.g., the death of another person during the decedent's lifetime)."28 It would also appear that the transfer in question might be taxed under section 2037 as a transfer taking effect at death.

\section{Annuities}

Section 2039 was added to the estate tax by the 1954 Code for the purpose of taxing benefits provided for an employee's dependents by his employer. It promises, however, to become principally a vehicle for avoiding a tax upon such benefits.

The statute expressly provides that benefits which are paid to the beneficiaries of a deceased employee under a qualified pension or profitsharing plan are exempt from the estate tax to the extent that they are paid for by the employer. Under the proposed regulations, the Treasury took the position that payments under qualified plans were only exempt if they took the form of a joint and survivor annuity, which was otherwise taxable under section 2039 (a) or (b), and that, consequently, insurance, which is not taxed under section 2039(a), was not

\footnotetext{
${ }^{23}$ U.S. Treas. Reg. 105, \& 81.20(b) (1942).

${ }^{24}$ U.S. Treas, Reg. $\$ 20.203^{8-1}$ (b) (1 958 ).

95 See Lowndes \& KraMer, Federal Estate and Gift Taxes 201 (1956).

${ }^{20}$ U.S. Treas. Reg. \$ 20.2036-I (b) (3) (1958).
} 
exempt under section 2039 (c). ${ }^{27}$ The Treasury has abandoned this position in the final regulations. Even insurance which is paid under a qualified plan will be exempt from the tax under section 2039 (c).$^{28}$

Since the tax under section 2039(a) is phrased in terms of a tax upon joint and survivor annuities, a payment under a plan which is not a qualified pension or profit-sharing plan may still be exempt from the estate tax if the decedent, at the time of his death, was neither receiving, nor had any right to receive, payments under the plan. ${ }^{29}$ Thus, it would appear that if an employer set up a plan under which his only obligation was to pay annuities to designated beneficiaries of his employees' after their deaths, these benefits would not be taxed to the employees' estates under section 2039, and probably not under any other section of the law, although this is not completely clear. In this connection, however, the regulations provide that a tax cannot be avoided by setting up two plans, under one of which payments will be made to the employee, and under the other of which payments will be made to his designated beneficiary, since both plans will be treated as components of a single plan. ${ }^{30}$

\section{Joint interests}

There is a widely-held misconception among the laity to the effect that it is possible to transmit property at death without incurring an estate tax by taking title to the property in the names of the purchaser or owner of the property and another as joint tenants or tenants by the entirety. Of course, this is not true. Although there is technically no testamentary or intestate transfer upon the death of a joint owner, but the indivisible title continues in the surviving tenant, the joint property is taxed to the decedent's estate according to his contribution to the property. ${ }^{31}$ Thus, for example, if $A$ buys Blackacre and takes title in his name and that of $B$ as joint tenants with right of survivorship, upon $A$ 's death, the full value of Blackacre will be taxed to his estate. ${ }^{32}$ As previously indicated, ${ }^{33}$ however, it may be possible to minimize the tax upon jointly held property by having the joint tenant who contributed the consideration for the property transfer his interest in the property before his death. Even though the transfer is in contemplation of death, it has been held that only the transferor's fractional interest in the prop-

\footnotetext{
${ }^{27}$ Proposed U.S. Treas. Reg. $§ 20.2039-2$ (a) (1956).

${ }^{28}$ U.S. Treas. Reg. \& 20.2039-2(b), example (3) (1958).

${ }^{20}$ Id. § 20.2039-1(b). ${ }^{80}$ Id. $\S 20.2039-1$ (b), example (6).

${ }^{31}$ INT. REV. CODE OF 1954, § $2040 . \quad{ }^{32}$ Ibid.

${ }^{33}$ See the discussion under Transfer in contemplation of death, supra p. 183.
} 
erty, rather than the entire property, will be taxed to his estate. ${ }^{34}$ This view was accepted by the proposed regulations. ${ }^{35}$ The deletion of the Treasury's acquiescence on this point in the final regulations appears to indicate, however, that it is still unsettled.

\section{Life insurance}

Life insurance is an especially appealing subject for an intervivos gift to reduce death taxes. Since this is not the kind of property which a man expects to enjoy during his life, it involves no great hardship to part with it before his death. Moreover, when life insurance is given away, the gift tax is limited to the then value of the insurance. Consequently, by giving away insurance before it has accumulated any substantial reserve, a man may avoid an estate tax upon the face amount of the insurance by paying a gift tax upon a small fraction of this sum. The 1954 Code encourages intervivos gifts of life insurance to avoid estate taxes by abolishing the "premium payment" test and providing that life insurance payable to beneficiaries other than the insured's estate will not be taxable to the insured's estate if the insured completely divested himself of all incidents of ownership in the insurance before his death.

The regulations interpret the new method of taxing life insurance generously. Thus, it is provided that the possibility of inheriting insurance from a transferee of the insurance is not an incident of ownership which will make the insurance taxable to the insured's estate, even though a reversionary interest which is worth more than five per cent of the value of the policy at the insured's death is regarded as an incident of ownership. ${ }^{36}$ Furthermore, even though the insured retains a reversionary interest in an insurance policy, if the transferee has power to cash in the policy, it will not be taxed to the insured's estate, upon the theory that the transferee's power to cash in the policy and defeat the insured's reversionary interest prevents the reversionary interest from being worth more than five per cent of the value of the policy.7?

\section{B. Successive Estates}

One popular method of minimizing estate taxes involves the creation of successive estates to avoid successive estate taxes. The difficulty with

\footnotetext{
"sullivan's Estate v. Commissioner, I75 F.2d 657 (9th Cir. 1949).

${ }^{36}$ Proposed U.S. Treas. Reg. § 20.2040-I (d) (1956).

${ }^{20}$ U.S. Treas, Reg. § z0.2042-1 (c) (3) (1958).

"Ibid.
} 
successive estates from the estate-planning point of view is that they are apt to be rigid and inflexible. This can be overcome, however, without encountering the second tax, by using nontaxable powers of appointment. The new regulations are quite liberal in their definition of nontaxable powers of appointment. A concrete illustration will make this clearer.

Suppose that $A$ dies and leaves his estate to $T$ in trust to pay the income to $A$ 's son, $B$, during $B$ 's life, and at $B$ 's death, to distribute the trust property in equal shares among $B$ 's children, $A$ 's grandchildren. Although this type of settlement will avoid a second tax at $B$ 's death, it has several disadvantages as contrasted with an outright gift to $B$ in fee. If $B$ needs the principal of the trust during his life, he cannot get it. Nor can he make provision for the support of his wife out of the trust if she survives him. Finally, the trust property will be distributed to $B$ 's children in equal shares at $B^{\prime}$ s death, regardless of their needs and merits. All of these objections can be overcome by the use of nontaxable powers of appointment, without incurring a second tax at $B$ 's death.

Thus, for example, $B$ may be given power to invade the corpus of the trust for his support without making the property taxable to his estate at his death. ${ }^{38}$ Under the proposed regulations, there was some indication that support might be construed strictly, so that it would not include whatever was necessary to maintain the donee in his accustomed manner of life if he lived very lavishly. ${ }^{39}$ The final regulations provide expresssly, however, that a power to invade property will not be taxable if it is limited to the donee's "support in his accustomed manner of living."40 The final regulations make it clear that broad powers to invade trust property for the donee's health, support, or education will not be taxable.

Of course, in the hypothetical situation, $B$ may be given power to appoint all or part of the trust property, such as the income from the trust, to his wife, without incurring a tax. This is a nontaxable power, since it does not include power to appoint to himself, his estate, his creditors, or the creditors of his estate. He may also be given power to appoint to his children without incurring a tax, since this is a nontaxable power. Under the new regulations, it. is expressly provided that a power may be worded in broad negative terms without incurring a tax. Thus, a power which expressly authorizes the donee to appoint to any-

\footnotetext{
${ }^{83}$ INT. REV. CODE OF 1954, \& $204 \mathrm{r}$ (b) ( I) (A).

${ }^{80}$ Proposed U.S. Treas. Reg. $\$ 20.2041-1$ (c) (2) (1956).

${ }^{40}$ U.S. Treas. Reg. $\$ 20.204 \mathrm{I}-\mathrm{T}(\mathrm{c})(\mathrm{z})$ (1958).
} 
one except the donee, his estate, his creditors, or the creditors of his estate is not taxable. ${ }^{41}$

When a person has a power of appointment, the new regulations should be read carefully to determine whether this is a pre-1942 power or a post-r 942 power, since there is no tax upon a pre-existing power, even though it is a general power, if the power is not exercised. The powers which the regulations classify as pre-existing, or pre-1942, powers may occasion some surprise. Thus, for example, a power created by a will executed before October 22, 1942 is a pre-existing power, even though the testator died after October 2I, I942, provided that he died before July I, I949 and that he did not republish the will after October 2I, 1942.42 Again, if in 1940, $A$ conveyed property to $T$ in trust for $C$ for life, remainder to whomsoever $C$ should appoint by will, and remainder, in default of appointment, to $D$ for life and to whomsover $D$ should appoint by will, and $C$ died after October 2I, I942, without exercising the power, the power vested in $D$ would be a pre-existing power. The regulations provide that "a power of appointment is not considered as created after October 2I, I942 merely because the power is not exercisable or the identity of its holders is not ascertainable until after that date." ${ }^{33}$ Suppose that $A$ in I940 conveyed property to $T$ in trust for $C$ for life, remainder to whomsoever $C$ should appoint by will, and remainder, in default of appointment, to $D$ and his heirs, and reserved a power to revoke this trust, which he released in I943, when was $C^{\prime}$ 's power created? According to the regulations, $C^{\text {'s }}$ power was created after October 2I, I942, when $A$ released the power to revoke the trust. ${ }^{44}$ According to the decision in Merchant's National Bank of Mobile v. United States, ${ }^{45}$ however, the power was created when $A$ transferred the property to the trustee before October 22, 1942.

\section{Deductions}

One way to keep an estate tax at a minimum is to utilize fully the deductions which are allowed under the statute. Ordinarily, this involves post-morten planning-making sure that the estate takes all the deductions to which it is entitled after the decedent's death. There are some situations, however, where the deductions which are available to an estate after the decedent's death depend upon the way in which the estate was planned during his life. This is true of the charitable and the mari-

\footnotetext{
${ }^{41} I d . \S 20.2041^{-1}$ (c) (I).

43 Ibid.

${ }^{4} I d . \S 20.204$ I-I (e).

"Ibid.

${ }^{15}{ }_{5} 6$ F. Supp. 827 (S.D. Ala. 1957), aff'd, FED. EST. \& GiFT TAX REP. If x 1,836 (5th Cir. 1958).
} 
tal deductions. The new regulations do not lay down any startling new rules for the charitable and marital deductions, but they do point out some precautions which should be observed to make sure that these deductions will be available.

\section{r. Charitable transfers}

In connection with the deduction for charitable transfers, for example, the new regulations provide that a deduction will not be allowed for a gift of income to charity unless it is sure that the charity will get the income. Thus, section 20.2055-2(b) declares:

The deduction is not allowed in the case of a transfer in trust conveying to charity a present interest in income if by reason of all the conditions and circumstances surrounding the transfer it appears that the charity may not receive the beneficial enjoyment of the interest. For example, assume that assets placed in trust by the decedent consist of stock in a corporation the fiscal policies of which are controlled by the decedent and his family, that the trustees and remaindermen are likewise members of the decedent's family, and that the governing instrument contains no adequate guarantee of the requisite income to the charitable organization. Under such circumstances, no deduction will be allowed. Similarly, if the trustees are not members of the decedent's family but have no power to sell or otherwise dispose of the closely held stock, or otherwise insure the requisite enjoyment of income to the charitable organization, no deduction will be allowed.

\section{The marital deduction}

The 1954 Code liberalized the marital deduction by providing that property given to a surviving spouse for life, with a power to appoint the remainder to herself or her estate, qualifies for the marital deduction, even though the gift is outright rather than in trust. Moreover, under the I954 Code, even though a surviving spouse is given only income from a specific portion of the property left by a deceased spouse and power to appoint this specific portion to herself or her estate, a marital deduction will be allowed pro tanto for this specific portion. ${ }^{46}$

The new regulations construe the amendments to the marital deduction liberally, by providing that despite the literal language of the

\footnotetext{
${ }^{40}$ INT. REv. CODE OF 1954, § $2056(\mathrm{~b})-5$ (b).
} 
statute, the surviving spouse need not be given the income from and the right to appoint the same specific portion in order for the transfer to the surviving spouse to qualify for the marital deduction. Thus, for example, if $H$ dies and leaves property to $T$ in trust to pay half of the income from the property to $W, H$ 's wife, during her life, and at her death, to pay over one-quarter of the property to whomsover $W$ appoints by her will, one-quarter of the property will qualify for the marital deduction. Where the specific portion from which the surviving spouse is entitled to income differs from that which she is empowered to appoint, a marital deduction will be allowed, but it will be limited to the smaller portion. ${ }^{47}$

In connection with the gift of a specific portion to a surviving spouse, it should be noted that the regulations interpret "specific portion" to mean a fractional or percentile interest in the property left by the decedent rather than a specific dollar amount. For example, if $H$ dies and leaves a million dollars to $T$ in trust to pay the income from the property to $H$ 's wife, $W$, during her life, and at her death, to pay over $\$ 500,000$ to whomsover $W$ may appoint by her will, no part of the trust qualifies for the marital deduction..$^{48}$

Under some of the recent decisions, there is considerable uncertainty as to whether a power which is given to a surviving spouse to consume trust property is a power to appoint the property which qualifies the trust property for the marital deduction. ${ }^{49}$ The new regulations do little to dispel this confusion. Although it is asserted that "an unlimited power to invade" satisfies the power of appointment requirement for the life-estate-power-of-appointment exception to the nondeductible terminable interest rule, ${ }^{50}$ it is also provided that ${ }^{51}$

In order for a power of invasion to be exercisable in all events, the surviving spouse must have the unrestricted power exercisable at anytime during her life to use all or any part of the property subject to the power, and to dispose of it in any manner, including the power to dispose of it by gift....

In view of the ambiguous language of the regulations, it seems de-

\footnotetext{
"U.S. Treas. Reg. \$20.2056(b)-5(b) (1958).

${ }^{48} I d . \$ 20.2056(\mathrm{~b})-5(\mathrm{c})$.

${ }^{48}$ See Commissioner v. Ellis' Estate, 252 F.2d 109 (3d Cir. 1958); Estate of Pipe v. Commissioner, 241 F.2d 210 (2d Cir.), cert. denied, 355 U.S. 814 (1957).

${ }^{b 0}$ U.S. Treas. Reg. $\S 20.2056(\mathrm{~b})-5(\mathrm{~g})(1958)$.

${ }^{61}$ Id. $\$ 20.2056(\mathrm{~b})-5(\mathrm{~g})(3)$.
} 
sirable, if one wants to qualify a gift for a surviving spouse for the marital deduction, to give her power to appoint the property to herself or her estate in unmistakable terms, instead of relying upon a power to invade or consume the property.

\section{Valuation}

One way of minimizing an estate tax is to keep the value of the estate as low as possible. As far as tax economies are concerned, every dollar which is squeezed out of the tax base represents an equal saving, regardless of whether this results from excluding property from the taxable estate or reducing the value of the property in the taxable estate. Ordinarily, the proper valuation of an estate presents a problem in postmortem planning to make sure that the estate is not overvalued. There are, however, situations where it is possible to control valuation by planning in advance of death. A notable instance is a business purchase agreement.

\section{Business purchase agreements}

Interests in a closely-held business, like a partnership or a close corporation, are especially vulnerable to overvaluation because of the government's tendency to overemphasize the intangible assets of the business, such as good will. To combat this, it has become quite common for business associates to enter into agreements by which, upon the death of one of them, the survivors are entitled to buy his interest at a designated price. Such an arrangement affords not only an orderly method of liquidating the decedent's interest in the business at his death, but a ceiling upon its valuation under the estate tax.

The new estate tax regulations encourage the use of such agreements by explicitly providing that they will control valuation for estate tax purposes, provided that "the agreement represents a bona fide business arrangement and not a device to pass the decedent's shares to natural objects of his bounty for less than an adequate and full consideration in money or money's worth." ${ }^{352}$ Although the regulations are vague about what specific arrangements will fix the value of an interest in a business for estate tax purposes, they are significant in that they recoguize the existence of such agreements.

It is fairly clear from the regulations that an agreement will not conclusively determine the value of an interest in a business unless the decedent's estate is obligated to sell the interest at his death, although

\footnotetext{
${ }^{50} I d . \S 20.203 \mathrm{I}(\mathrm{h})$.
} 
it is sufficient if the surviving associates have an option to purchase the interest; they need not be under a binding obligation to do so. Furthermore, the decedent must have been restrained from selling his interest during his life, except to his associates at the designated price. ${ }^{53}$

It is not clear what further requirements the agreement must meet in order to qualify as a bona fide business arrangement rather than a disguised testamentary transaction. Presumably, the purchase price of the decedent's interest must not be less than its fair market value at the time the agreement was made or at the time of the decedent's death. An arm's length bargain between business associates, who are not related, will obviously excite less suspicion of being a disguised testamentary transaction than an agreement between members of the same family, who are natural objects of each other's bounty and the principal beneficiaries under each other's wills.

\section{II}

\section{$T_{\text {He Gift }} \mathrm{T}_{\mathrm{AX}}$}

From the point of view of the tax and estate planner, the gift tax is less important than the estate tax. With the exception of transfers to liquidate marital rights in connection with separation and divorce, no one need incur a gift tax, since there is no compulsion to make a gift. Ordinarily, the estate planner encounters the gift tax in connection with intervivos transfers to avoid the estate tax. Even when one is primarily interested in escaping the estate tax, however, it is desirable to keep gift taxes at a minimum. The new gift tax regulations point up some ways in which this may be done. The most significant portions of the new regulations appear to be those which seek to interpret the innovations under the gift tax which were made by the r954 Code. Pursuant to that premise, the discussion of the new gift tax regulations has been confined to (I) gifts to minors; (2) transfers in connection with divorce; and (3) the creation of joint estates in realty between spouses.

\section{A. Gifts to Minors}

Intervivos gifts to avoid the estate tax are frequently made to minors. Whenever possible it is desirable to cast such gifts in the form of gifts of present interests, in order to take advantage of the annual exclusion, but this is especially desirable where the gift consists of a trust which is to be funded by periodic contributions. Thus, for example, a married man who sets up a trust for a new-born infant can contribute

\footnotetext{
"Ibid.
} 
$\$ 126,000$ tax-free to the trust during the minority of the beneficiary ( $\$ 6,000$ a year for twenty-one years) by splitting his contributions with his spouse and utilizing their annual exclusions, without encroaching upon his gift tax exemption.

Under the r939 Code, due to the infant's inability to hold property for himself, there was considerable confusion about what gifts to minors constituted gifts of present interests which qualified for the annual exclusion..$^{54}$ To clear up this uncertainty, section 2503 (c) was added to the gift tax by the 1954 Code. Under this section, a gift to a minor is deemed to be a gift of a present interest if it meets the following conditions:

(r) The income and principal of the gift may be expended by or for the benefit of the minor during his minority.

(2) Any portion of the property not disposed of before the minor reaches twenty-one inust be paid to him when he attains that age.

(3) If the minor dies under twenty-one, the property must be distributed to his estate or to those to whom he appoints the property under a taxable power of appointment.

The regulations interpret this section of the statute quite liberally. Thus, they provide that section 2503 is not exclusive, but a gift to a minor which qualified as a gift of a present interest before section 2503 (c) was passed will continue to do so under the 1954 Code. .5

The regulations are also very generous in their interpretation of the statutory conditions which a gift to a minor must meet to qualify as a gift of a present interest under section 2503 (c). Thus, for example, it is provided that the requirement that income and principal may be expended for the minor during minority will be satisfied if the trustee has discretion to make such expenditures or to accumulate and retain the trust property during the infant's minority. ${ }^{\text {to }}$ The requirement that the property must be paid over to the minor when he reaches twentyone will be met even though the property is held under a trust which the minor may extend beyond this time. ${ }^{57}$ The most remarkable concession made by the regulations is the statement that the requirement

"See Lowndes \& KRAMER, FEDERAL ESTATE aND GIFT TAXES 772-84 (1956).

${ }^{B s}$ By way of illustration, $\S 25.2503-4$ (c) says that " $a$ transfer of property in trust with income to be paid annually to a minor beneficiary and corpus to be distributed to him upon his attaining the age of 25 is a gift of a present interest with respect to the income but is a gift of a future interest with respect to the right to corpus."

${ }^{50}$ U.S. Treas. Reg. § 25.2503-4(b)(1) (1958).

${ }^{67}$ Id. $\$ 25.2503-4$ (b) (2). 
that the beneficiary must have a taxable power to appoint the property if he dies under twenty-one and it is not payable to his estate is satisfied even though under the local property law the beneficiary is incapable of exercising the power as long as he is a minor. ${ }^{58}$ Since the gift to the minor is not disqualified for the annual exclusion because the property will go over to a designated taker in default of appointment, ${ }^{50}$ this means that a gift to a minor will qualify for the annual exclusion even though if the minor dies before he reaches twenty-one, the property will go to one designated by the donor rather than the infant donee.

\section{B. Transfers in Connection with Divorce}

In an effort to dispel the uncertainty as to whether or not transfers to settle up marital rights in connection with divorce are taxable as gifts, section 2516 was written into the gift tax by the 1954 Code. Section 2516 provides that a transfer to a spouse in settlement of marital or property rights, or to provide reasonable support for the minor issue of the marriage, shall be deemed to have been made for an adequate and full consideration (and, consequently, not to be a taxable gift), provided the transfer was pursuant to a written agreement between the spouses which was followed within two years by a divorce. Section 2516 raises a number of problems which the final regulations make no effort to solve.

Thus, for example, the proposed regulations provided that a transfer pursuant to a divorce decree was not taxable as a gift, ${ }^{\circ 0}$ in line with the decision of the Supreme Court in Harris v. Commissioner. ${ }^{\text {in }}$ There was, moreover, the basis for an inference from the care with which the proposed regulations referred to transfers "in settlement of their dower, curtesy, or other property rights" ${ }^{32}$ that a transfer in satisfaction of a spouse's right to support might not be taxable as a gift, even though it did not conform to section $2516 .{ }^{63}$ The final regulations, however, merely paraphrase the language of section 2516 , without undertaking to amplify or explain it. ${ }^{\text {es }}$ There is no indication as to whether or not section 2516 is exclusive, so that a transfer which falls without the language of that section will necessarily be taxable. Consequently, the prudent

\footnotetext{
"Id. $\$ 25.2503-4$ (b).

${ }^{\circ}$ Proposed U.S. Treas. Reg. $\$ 25.2516-1$ (c) (1957).

12340 U.S. 106 (1950).

"Proposed U.S. Treas. Reg. \$ $25.2516-1$ (c) (1957)'.

"See E.T. 19, 1946-2 C.B. 166.

"U.S. Treas. Reg. $\$ 25.2516$ (a) (1958).
} 
planner will make every effort to see that post-marital transfers follow the precise pattern prescribed by section 2516, in order to avoid a gift tax, until the scope of that section is more clearly delineated than it is under the new regulations.

\section{Creation of Joint Estates in Realty between Spouses}

Ordinarily, when a person transfers property to himself and another as joint tenants or tenants by the entirety, he makes a taxable gift of the interest which the transferee acquires in the jointly-held property. Section 2515 of the 1954 Code makes an exception to this rule in the case of the creation of joint tenancies and tenancies by the entirety in real estate between spouses. Where a spouse transfers real property to himself and his spouse as joint tenants or tenants by the entirety, he will not be treated as having made a taxable gift unless he affirmatively elects to treat the transfer as a gift and files a gift tax return. In this situation, however, there will be a taxable gift when the tenancy is terminated in any way other than by the death of one of the cotenants and one of the joint owners receives part of the property or its proceeds greater than his proportionate contribution to the property. Thus, for example, if $H$ purchased Blackacre and took title in his name and that of $W$ as tenants by the entirety and did not elect to treat this as a gift, and, subsequently, $H$ and $W$ sold Blackacre and divided the proceeds equally, $H$ would make a gift to $W$ at that time of the half of the proceeds which $W$ received.

The new regulations point this out, along with some corollaries from the basic statutory premise that there is no taxable gift until the termination of the tenancy, which the tax planner should keep in mind. Thus, for example, suppose that $H$ buys Blackacre and takes title in his name and that of $W$, his wife, as joint tenants, and does not elect to treat this as a taxable gift. Later, $W$ gives her half of the property to $X$. According to the regulations, $W$ has made a gift of her half of the property to $X$, and since this gift terminates the joint tenancy, there has also been a gift of this half of the property from $H$ to $W .^{\circ 5}$ If in the hypothetical situation, both $H$ and $W$ had conveyed their interests in Blackacre to $X$, there would have been a gift to $X$ by $H$ of his half of the property, a gift to $X$ by $W$ of her half of the property, and a gift to $W$ of half of the property by $H$ upon the termination of the joint tenancy.

\footnotetext{
${ }^{05} I d . \$ 25.2515^{-1}(\mathrm{~d})$.
} 
One thing which the new regulations do not point out in connection with the creation of joint estates in real property between spouses is the fact that in some situations, it may be advantageous for the donor spouse to elect to treat the creation of the tenancy as a gift, in order to avoid adverse tax consequences when the tenancy is later terminated. If, for example, $H$ takes title to Blackacre in his name and that of $W$ as joint tenants, and Blackacre is not worth more than $\$ 12,000$, it would ordinarily be advantageous for $H$ to elect to treat the creation of the tenancy as a taxable gift. $H$ would not incur any gift tax, since the gift of half of the property to $W$, which is worth $\$ 6,000$, would be wiped out by the marital deduction of $\$ 3,000$ and the $\$ 3,000$ annual exclusion. If later, however, $H$ and $W$ wished to terminate the tenancy by giving away Blackacre, or they wished to divide the property equally between them, this could be done without incurring any gift tax upon a transfer by $H$ to $W$. This might be a valuable privilege if Blackacre had increased in value, so that any transfer between $H$ and $W$ would not be taken care of by the marital deduction and the annual exclusion. 